\title{
The Edible Woman: A Perspective of Women
}

\author{
Moirangthem Dolly \\ M.A.(English), UGC-NET, B.Ed. \\ India \\ alizeeraj@gmail.com
}

\begin{abstract}
In many respects, The Edible Woman was created during a 'whirlwind change'. Atwood successfully links together 'ideas of marriage' and 'consumerism' as related to the ideas and the perceptions of the self. In this novel, Atwood produces a world centred around a young woman, Marian MacAlpin, who is thrust into the role of fiancé and the traditional position. The Edible Woman is successful because it pulls us into Marian's world and makes us a part of it. Things at first appear to be crystal and real. The moments of her daily life are presented in ways that a reader can relate to. Marian's life seems acceptable and worthwhile. This paper highlights a perspective of women through Marian, the protagonist of Atwood's The Edible Woman.
\end{abstract}

\section{Keywords :-}

Edible, Whirlwind Change, Consumerism, Marriage.

\section{Introduction :-}

Margaret Atwood, an internationally well-known Canadian writer was born on $18^{\text {th }}$ November, 1939 in Ottawa, Canada. She is the author of more than forty works, including fiction, poetry and critical essays, and her books have been published in over thirty-five 
countries. Atwood is today's leading fiction writer. Of her novels, The Blind Assassin won the '2000 Booker Prize' and 'Alias Grace' won the Giller Prize in Canada and the Premio Mondello in Italy. In 2005, she was the recipient of the Edinburgh Book Festival enlightenment Award, for a distinguished contribution to world literature and thought.in 2008, Margaret was awarded the Prince of Asturia's Prize for Literature in Spain. She lives in Toronto.

"Margaret Atwood is one of the most brilliant and unpredictable novelists alive" - Literary Review.

The novel is structured into three parts beginning in first person, leading upto a point where Marian begins to crumble and eventually has to try and break free. But it is a false climax that has led into Marian's seeming acceptance of her role as fiancé. But it is at this point that the work jarringly switches to a third person narrative that allows hovering ominously above Marian's life and her actions until she finally breaks free for reality. At this point, the novel glides to its final resolution again in first person. 'The Edible Woman' is really the romantic comedy turned upside-down because once the girl gets engaged it virtually is a downhill battle that may or may not end up with her at the altar.

The novel also contains perhaps the most interesting character; that of Duncan, an educated young man who is in a deeper state of self-questioning than Marian ever will be. His place in the novel is small, thin, unattractive, yet, at the same time, important and revelatory without Duncan, there is no 'Edible Woman'.

Every character in the novel deals with each topic differently. In Ainsely, we see a woman who wants to fall pregnant with anyone she can because she believes it is her right to have a child. She longs to be a mother and soon entraps a man for the job. Her morals are not only scandalous but also paint a picture of what was expected from women at the time. On the flipside, we have Marian's friend Clara who dropped her normal life to marry and has 
three children. She is the epitome of what Marian could become, and again, heightens the fear. Marian describes as saying -

"Her metaphor for her children included barnacles encrusting a ship and limpets clinging to a rock."

One can see how Marian could find her fear in such a statement.

Well, the 'need' for motivational attachment is found in the 'Office Virgins' (Lucy, Emmy, Millie) too with whom Marian works and they are seen as being desperate for a man, any man, to sweep them out of the office and into the bedroom then kitchen.

Lida Hutchen, author and feminist critic describes. "Marian is potentially Everywoman." She indicates, "the novel warns us about the dangers of 'accepting the victim role' in a consumer society". As juxtaposed through Duncan, the arch of Marian's Ordeals reminds us to keep cool and questioning mind. Through its comic twists and turns, "The Edible Woman' reminds us to enjoy life as well as to question and be wary of it.

Atwood perceives a vital dynamic relationship between 'individual nature' and 'social nature'. It announces paradoxically that society is important for individual because an individual's behaviour is conditioned by social expectations and suggests even that for society itself, individual is important because only individuals care about what others think of them. Marian asserts are genuine, metaphysical, philosophical identity and reality. She is alienated and driven by her desire for recognition, as a result of which her personal self is split into parts. As she loses parts of herself, she realizes that she loses herself entirely and she moulds herself into a 'role' which she plays in the society. Here, Marian rebels against her social destiny.

Marian's refusal to eat can be viewed as resistance to being coerced into a more feminine role. In a description of Peter's (Marian' fiancé) apartment, Marian describes the 
"clutter of raw materials" that had through "digestion and assimilations" become the walls of the lobby. She sees that construction precedes consumption.

Brooks Bouson says -

"Atwood deploys her female protagonist, Marian MacAlpin, to expose and subvert the ideological constructs that have defined and confined women."

The body's assimilation of raw materials (food) is analogous to the social body's assimilation and processing of women into socially acceptable feminine subjects. By not eating, Marian refuses to take in the raw materials used to reconstruct her into a role of domesticity. This struggle is made explicit when one of Duncan's roommates expounds on 'Alice's Adventure in Wonderland' as having a 'sexual identity-crisis', then, goes on to describe the structure of both 'Alice' and 'The Edible Woman'.

"One sexual role after another is presented (to the heroine) but she seems unable to accept any of them." Marian is shaped first by her parents' plan for her future, then, by Peter's. Once married, Marian fears Peter's strong personality will obliterate her fragile identity. This subconscious perception of Peter as predator is manifested by Marian's body as an inability to eat, as a gesture of solidarity with other prey following her engagement, the switch to third person narrative shows that Marian's story is controlled by someone other than Marian herself; following Marian's regaining of identity, Atwood returns to first person narration.

Although she has made effort to adjust herself to the socially acceptable role, it is her imagination which is subversion force. The pattern is signalled in her first attempt when she runs away from Peter and Len. This attempt is fuelled by Marian's subconscious identification with the 'rabbit' in Peter's story and then confirmed by her recapture.

"I felt myself caught, set down and shaken. It was Peter who must have staked me." 
In response to society's control, Marian attempts to remove her body from its patriarchal strong hold when she crawls under a bed to hide from "the reverberating hot glare" of Peter. Her behaviour symbolically shows her endeavour to escape patriarchal society. Coral Ann points out that "Marian's misperception of Peter and her refusal to ingest food represent that social system makes Marian sick"; which shows Marian's psychic resistance to the role of social conformity. Marian's inner self is submerged under her social self and she is struggling against this division. When she was sitting on her dressing, seeing her reflection between dark and blonde dolls which are propped on the dresses, the entire episode of 'dolls' reveals Marian's inner self is in opposition to her social self and she is unable to reconcile the two. Marian's 'identity crisis' is converged through the reflections she sees of herself in different objects. She thinks of manipulating her image, but her single image breaks into three images. The three images reflect her own water logged body and she gets surprised by the fact that the three images move with each move that she makes on the bath tub and they are not identical: "The two on the outside were slanted inwards towards the third."

Thus, her own 'self' has fragmented and divided away from her.

Marian loses any sense of herself as unified subject and hallucinates her emotional conflict in images of fragmentation -

"She was afraid even to blink, for fear that this applied face would crack and flake with the strain."

Patricia Goldblatt opines that: "Marian's body and mind have split away from each other. She tries to reason with her body accusing it of having frivolous whims."

Atwood demonstrates Marian's growing alienation from her body. At the company Christmas Party, Marian looks around at the other women, thinking - 
"You were green and then you ripened, became mature. Dresses for the mature figure. In other words fat."

Marian refuses to become fat which would transform her into a woman and as such be constrained by a sexist culture. Marian is therefore alienated from nature as she places herself outside the process of maturation. Later in her engagement party, Duncan's question, "You did not tell me it was masquerade, who the hell you are supposed to be?", brought Marian 's subconscious rejection to the conscious level and made her realize the unauthenticity of her appearance. The party provided Marian a perception that Peter has a strong motive to negate her individuality and autonomy, by expecting her to assure the role of a traditional wife in the society. T.N. Dhar points out that:

"Her beliefs and modes of thought are out to a strenuous test till after being battered in the body and psyche, she finally passes into a state of 'raised consciousness,".'

Marian now believes that she should have never worn 'red' as a result of which she avoids mirror and feels relieved for not having been fixed, in a photograph. According to Atwood's own words, "the novel makes negative statement about society, the complications are resolved but not in a way that affirms the social order". Further Duncan says to Marian, "It is your personal cul-de-sac you invented it, you'll have to think of your own way out of it". It is with this exhortation to responsibility that Marian leaves the ravine. The inversion of the knowledge of shadow self and shady self about her 'self' and about the 'other', persuades her to return to her apartment and take off the red sequined dress which had her a target for Peter. Then, she washes her dishes and restores order in general and proceeds to bake a cake: "an elaborate cake cut and decorated to look like a woman in bright pink ruffled dress wearing her hair in intricate baroque scrolls and swirls," which was presented to Peter. Catherine Mclay states that Marian's cake represents: 
"a feast for the celebration of Marian's new freedom and even rebirth from her own spell, the identification of herself with the victim role. No longer isolated and alien, Marian has rejoined the society”.

The novel's publication coincided with the rise of the women's movement in North America, but is described by Atwood as 'proto-feminist' because it was written in 1965 and thus anticipated second wave feminism.

Marian wants to be free from the bondage of marriage traditional way. She struggles to show that women are not object or a thing which can be just eaten up. She tries to prove that women cannot always be used by men. Through Marian, Atwood satirizes the behaviour of both man and woman. She is yearning for a moral equality. The cake is a symbol of all those women who asked the question, "Is marriage a joke? How important a wedding is in the life of a woman?". Marian does not want simply an edible woman. She suggests the idea that women are used, abused, and abandoned by men in some cases so, she is asking all women to stand up and rebel for this.

\section{Conclusion :-}

Atwood's The Edible Woman is about women and their relationship with men, to society, and to food and eating. It is through food and eating that Atwood discusses a young woman's rebellion against a modern male dominated world. The female protagonist Marian MacAlpin, struggles between the role that society has imposed upon her and her personal definition of self. Food becomes the symbol of that struggle and her eventual rebellion. Patricia Goldblatt opines that "through Marian MacAlpin, Atwood creates a situation where all women should be brave, self-reliant personal in order to survive in a patriarchal society". The novel represents the conflict between one's body (external) and soul (internal). Marian wants a "woman of confined and spiritual beauty" and not just a physical beauty. Atwood 
does criticize both men and women. She shows that marriages without meaning 'is useless'. She puts forward the idea that there should be coordination between the two (man and woman). 


\section{References :-}

Toor Ms Gur Kiran, Feminist Elements and Ideas of Margaret Atwood in The Edible Woman, Vol. III, Issue. XXVIII, May 2017, online

Ulla Kriebernegg, "Neatly Serving the Body form the Head: Female Abjection In Margaret Atwood's The Edible Woman”, University of Graz, Austria, online.

Sofia Sanchez-Grant, "The Female Body in Margaret Atwood's The Edible Woman and Lady Oracle”, Journal of International Women's Studies, Volume 9 Issue 2, Pg 77-92, online.

Banerjee Prantik, "Surviving Consumerism and Eating Disorders in Margaret Atwood'sThe Edible Woman”, IOSR Journal of Humanities and Social Science (IOSR-JHSS) Volume 21, Issue 8, Ver.5 (Aug. 2016) PP 21-25, online.

Patel, Dilip R., "Feminist perspective in Margaret Atwood's The Edible Woman," Research Guru, Volume-11, Issue-3, December-2017, ISSN: 2349-26X, Pg 38-42, online.

Ellen McWilliams, "Margaret Atwood's Canadian Hunger Artist: Postcolonial appetites in The Edible Woman”, Kunapini, Volume 28 Issue 2, Article 9, online. 